\title{
Aerial plankton from the Eastern Tropical Pacific
}

\author{
Darko D. Cotoras ${ }^{1 *} \&$ Manuel A. Zumbado ${ }^{2}$ \\ 1. Department of Entomology, California Academy of Sciences, San Francisco, California, 94118, USA; \\ darkocotoras@gmail.com \\ 2. Instituto Nacional de Biodiversidad (INBio), A.P. 22-3100, Santo Domingo, Heredia, Costa Rica; \\ mzumbado@inbio.ac.cr \\ * Correspondence
}

Received 24-I-2019. Corrected 30-V-2019. Accepted 04-VII-2019.

\begin{abstract}
Introduction: Small terrestrial invertebrates disperse in a passive manner through wind currents, forming what is known as aerial plankton, which has not been surveyed yet for the Eastern Tropical Pacific. Documenting the aerial plankton of Isla del Coco will allow to better understand the colonization process of this highly diverse island. Objective: Characterize the aerial plankton present on the transect Puntarenas - Isla del Coco. Methods: Specimens were collected using entomological nets on 2 roundtrip voyages during the months of July and August of 2017 and 2018, respectively. Results: A total of 10 morpho-species were collected corresponding to the orders: Diptera (Ceratopogonidae, Milichiidae, and Nematocera of a non-identified family), Hymenoptera (Chalcidoidea: Agaonidae), Hemiptera (Scutelleridae and Coreidae) and Lepidoptera (Sphingidae). Diptera and Hymenoptera were collected on the nets; while, Hemiptera and Lepidoptera were found on the deck of the boat. No spiders were collected. The Diptera and Hymenoptera families, as well as the family Coreidae (Hemiptera), have been previously recorded on this type of surveys across the tropical Pacific. Conclusions: Two of the taxa collected by nets, Ceratopogonidae (Diptera) and Chalcidoidea (Hymenoptera), have representatives on Isla del Coco, which could provide direct support for wind dispersal as a colonization mechanism for these groups. We also detected other insects (i.e. Lepidoptera and Scutelleridae-Hemiptera) which most likely reached the boat by their own means providing evidence of their dispersal abilities. This research provides data to further expand on questions about the mechanisms of island colonization.
\end{abstract}

Key words: Long-distance dispersal; Aerial plankton; Arthropods; Eastern Tropical Pacific; Isla del Coco.

Cotoras, D. D., \& Zumbado, M. A. (2020).Aerial plankton from the Eastern Tropical Pacific. Revista de Biología Tropical, 68(Suppl.1), S155-S162.

Remote locations are colonized by longdistance dispersal (Jordano, 2017), the actual mechanism of colonization is organism-dependent (Gillespie et al., 2012). Large terrestrial animals use rafts of vegetation and their patterns of dispersal depend on surface marine current, as it has been the case for Anolis lizards in the Bahamas (Calsbeek \& Smith, 2003). A similar situation happens with plants with large seeds (Nathan et al., 2008). Some terrestrial organisms disperse attached to the body or inside the guts of migratory birds (Gillespie et al., 2012). For marine organisms, sea currents play an important role in defining the direction of the dispersal, while the larval duration will determine how far the organisms can be transported (Shanks, 2009).

Small terrestrial invertebrates disperse in a passive manner through wind currents, forming what is known as aerial plankton. Winged animals get caught on air currents while flying. In the case of spiders, they actively start dispersal 
with ballooning (Larrivée \& Buddle, 2011). The take-off required for ballooning could be initiated by different strategies as the tip-toe launch or from a suspended position at a high structure (Bell, Bohan, Shaw, \& Weyman, 2005). Given some environmental cues spiders start to spin silk to the air until it gets caught by wind currents. Simulations suggest that this behavior appears to be optimal in non-ideal convection conditions, which means warm temperatures with a light breeze (Reynolds, Bohan, \& Bell, 2007). Recent studies have shown that the time to perform this behavior is also favored by the detection of electric fields (Morley \& Robert, 2018). Ballooning has been showed to occur in open fields (Okuma \& Kisimoto, 1981) and closed forest (Larrivée \& Buddle, 2011). It is not exclusive for spiders, it also has also been reported on spider mites (Acari) and larvae of moths (Lepidoptera) (Bell et al., 2005).

Indirect evidence about the groups of organisms that disperse by wind currents was provided on the seminal experimental studies to test the hypothesis of island biogeography. Indeed, transport through rafts was described not as important as air-based colonization on the early stages of colonization after the experimental defaunation (Simberloff \& Wilson, 1969). Similarly, spiders were also among the early colonizers on land cleared by the volcanic explosion on the island of Krakatau (Bristowe, 1931).

Direct collections with entomological nets placed in airplanes and ships also demonstrate that there is an important amount of terrestrial invertebrates floating on the air column (Gressitt, Leech, \& O’Brien, 1960; Hardy \& Cheng, 1986). Surveys from ships going around Antarctica have demonstrated the presence of Araneida, Collembola, Psocoptera, Thysanoptera, Heteroptera, Coleoptera, Diptera, and Hymenoptera (Gressitt et al., 1960). Sub-Antarctic surveys combining land trapping and nets on ships have resulted in the collection of Acari, Collembola, Homoptera, Coleoptera, Diptera, and Hymenoptera (Gressitt, Leech, Leech, Sedlacek, \& Wise, 1961).
While, collections across the north tropical Pacific have reported Hymenoptera, Diptera, Coleoptera, Hemiptera, Thysanoptera, Arachnids (Yoshimoto \& Gressitt, 1960; Holzapfel \& Perkins, 1965) and even a marine bivalve (Yoshimoto \& Gressitt, 1961). Surveys on the East China Sea focused on arachnids, reported that the dominant (101 out of 105 specimens) genus was Tetragnatha (Tetragnathidae). The other families found corresponded to Theridiidae, Erigonidae, and Lyniphiidae (Okuma \& Kisimoto, 1981).

In the case of the Eastern Tropical Pacific, there are no previous reports of aerial plankton. Within the region, Isla del Coco is an oceanic island located $550 \mathrm{~km}$ from Costa Rica and $680 \mathrm{~km}$ from the Galápagos. Among the climatic features that characterize the island is the heavy rainfall $(7 \mathrm{~m})$, as a result of being in the path of the Intertropical Convergence Zone (ITCZ), and the presence of south-westerlies trade winds (Amador et al., 2005). The month of September is historically the one with the highest frequency of named tropical storms, hurricanes and major hurricanes (Amador et al., 2005). The island was originated on the Galápagos hotspot. The current emerged land has between 1.9 and 2.4 million years (Bellon, Saenz, \& Tournon, 1983; Castillo et al., 1988), which suggests it corresponds to later volcanic activity. Therefore, all the terrestrial biodiversity colonized during the last couple of millions of years. As is expected for a remote island, it lacks many groups of organisms of large size present in the continent.

The direct evidence from aerial trapping and indirect evidence from the species present on remote islands provide a clear idea of which groups are the most abundant and effective components of the aerial plankton. However, the amount of available data is geographically sparse and reduced. Increasing the number of locations will give a better picture of which are the most common groups at a global level or how do they compare between geographic regions. Also, better sampling in places like Isla del Coco will provide data to regionally understand the process of long-distance 
colonization. Here, we characterize the aerial plankton present on the transect Puntarenas Isla del Coco on 2 roundtrip voyages during July 2017 and August 2018. This study corresponds to the first report for this part of the tropical Pacific.

\section{MATERIALS AND METHODS}

Collections were performed during 4 travels on the transect Puntarenas - Isla del Coco: (1) $08^{\text {th }}-10^{\text {th }}$ July 2017 , (2) $23^{\text {rd }}-25^{\text {th }}$ July 2017 , (3) $12^{\text {th }}-14^{\text {th }}$ August 2018 and $22^{\text {nd }}-24^{\text {th }}$ August 2018. On trip number 1, an array with 10 entomological nets (approx. $50 \mathrm{~cm}$ diameter each) was placed around the boat (Fig. 1A, Fig. 1B). A similar arrangement was used on trip number 2, but with only 6 nets (Fig 1C). Nets were checked every 6 hours starting from the departure from Puntarenas or the island. On trips number 3 and 4, only one net was placed on towards the bow on the stern (Fig. 1D). The net was checked every 8 hours. The nets were cleaned and checked before being placed in the boat in order to ensure that all insects collected corresponded to aerial plankton. Whenever nets were checked the location was recorded with a GPS. Specimens collected were preserved in

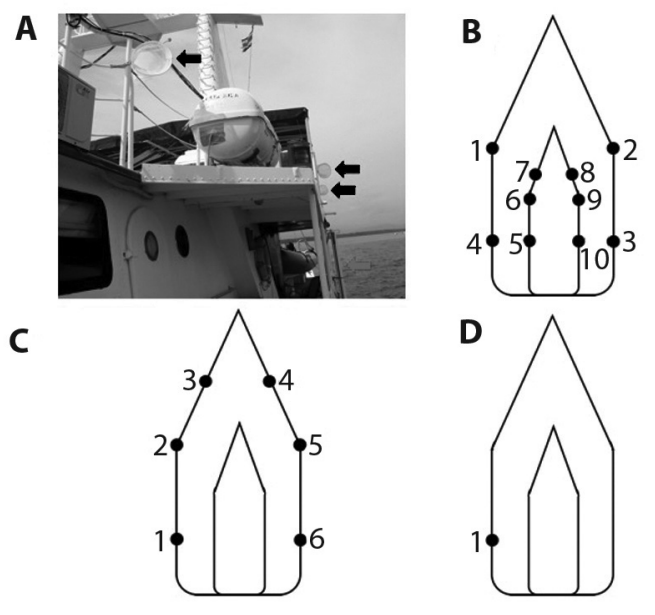

Fig. 1. Collecting arrangement (A) Picture of collecting nets in Okeanos I, (B) Distribution of collecting nets in Okeanos II (July, 2017), (C) Okeanos II (July, 2017), and (D) Okeanos II (August, 2018). ethanol $100 \%$. Opportunistic collections on the deck were also done and GPS point recorded.

\section{RESULTS}

On the first three trips, a total of 18 individuals were collected corresponding to 10 morpho-species from the orders: Diptera (Ceratopogonidae, Milichiidae, and a non-unidentified family of Nematocera), Hymenoptera (Chalcidoidea: Agaonidae), Hemiptera (Scutelleridae and Coreidae) and Lepidoptera (Sphingidae). The first two orders (Diptera and Hymenoptera) were collected on the nets, while the other two (Hemiptera and Lepidoptera) were found on the deck of the boat (Table 1-3). Each collection event corresponds to a single individual, except for the Sphingidae months, which numbers are specified on the tables. On the trip from Isla del Coco to Puntarenas departing on August 22nd 2018 nothing was collected.

\section{DISCUSSION}

Cross oceanic dispersal of small arthropods occurs through wind currents. The composition and geographic distribution of the aerial plankton are highly understudied, yet essential to understand island colonization processes. Here, we characterize the aerial plankton on the transect Puntarenas - Isla del Coco. This portion of the Eastern Tropical Pacific has not been previously surveyed and represents a high interest for the historical biogeography of the oceanic islands present on the region (Revillagigedo archipelago, Clipperton, Isla del Coco, Malpelo, and Galápagos).

Regardless a small sampling size of 4 trips ( 36 hrs. each) on the transect, with half of them using only one sampling net, it was possible to collect representatives of 3 different families: Ceratopogonidae, the unidentified Nematocera (Diptera) and Agaonidae (Hymenoptera). In terms of the total amount of specimens, this result is similar to previous studies across the Tropical Pacific where they collected around 
TABLE 1

Collections of aerial plankton on transect Puntarenas - Isla del Coco, during July 2017 onboard Okeanos I

\begin{tabular}{|c|c|c|c|c|c|}
\hline Point & Date & $\begin{array}{l}\text { Time } \\
\text { (hrs.) }\end{array}$ & Coordinates & $\begin{array}{l}\text { Distance to nearest } \\
\text { continental land }(\mathrm{km})\end{array}$ & Collections \\
\hline PUNTARENAS & July $8^{\text {th }}$ & $14: 25$ & $-84.835352^{\circ}, 9.980183^{\circ}$ & 0 & - \\
\hline AP1 & 2017 & $15: 25$ & $-84.784242^{\circ}, 9.869021^{\circ}$ & 6 & $\begin{array}{l}\text { Net \#5: Diptera: Nematocera, } \\
\text { probably Scatopsidae } \\
\text { Net \#6: Diptera: Nematocera: } \\
\text { Ceratopogonidae }\end{array}$ \\
\hline AP5 & & $20: 25$ & $-85.104346^{\circ}, 9.221228^{\circ}$ & 35 & $\begin{array}{c}\text { Net \#4: Diptera: Nematocera: } \\
\text { Ceratopogonidae }\end{array}$ \\
\hline AP8 & July $9^{\text {th }}$ & $2: 25$ & $-85.513157^{\circ}, 8.454209^{\circ}$ & 130 & - \\
\hline AP9 & 2017 & $8: 25$ & $-85.921614^{\circ}, 7.682497^{\circ}$ & 226 & - \\
\hline AP10 & & $14: 25$ & $-86.341958^{\circ}, 6.886541^{\circ}$ & 325 & $\begin{array}{l}\text { Net \#9: Hymenoptera: } \\
\text { Chalcidoidea: Agaonidae }\end{array}$ \\
\hline AP11 & & 21:00 & $-86.799227^{\circ}, 6.030168^{\circ}$ & 432 & - \\
\hline ISLA DEL COCO & $\begin{array}{c}\text { July } 10^{\text {th }}, \\
2017\end{array}$ & $\begin{array}{l}\text { Approx. } \\
\text { 8:00 }\end{array}$ & $-87.055579^{\circ}, 5.544034^{\circ}$ & 492 & - \\
\hline
\end{tabular}

TABLE 2

Collections of aerial plankton on transect Isla del Coco - Puntarenas, during July 2017 onboard Okeanos II.

\begin{tabular}{|c|c|c|c|c|c|}
\hline Point & Date & $\begin{array}{l}\text { Time } \\
\text { (hrs.) }\end{array}$ & Coordinate & $\begin{array}{c}\text { Distance to nearest } \\
\text { continental land }(\mathrm{km})\end{array}$ & Events \\
\hline APR1 & July $23^{\text {rd }}$, & $14: 45$ & $-86.977001^{\circ}, 5.641371^{\circ}$ & 479 & - \\
\hline APR2 & 2017 & $20: 45$ & $-86.587383^{\circ}, 6.395585^{\circ}$ & 385 & - \\
\hline APR3 & July $24^{\text {th }}$, & $3: 54$ & $-86.103414^{\circ}, 7.323246^{\circ}$ & 270 & - \\
\hline APR4 & 2017 & $8: 45$ & $-85.744103^{\circ}, 7.989793^{\circ}$ & 187 & $\begin{array}{c}\text { Deck: Diptera: Nematocera: } \\
\text { Ceratopogonidae }\end{array}$ \\
\hline (AP4.1R) & & $14: 25$ & $-85.334508^{\circ}, 8.761253^{\circ}$ & 92 & $\begin{array}{l}\text { Deck: Diptera: } \\
\text { Acalyptratae: Milichiidae }\end{array}$ \\
\hline AP5R & & $14: 52$ & $-85.318124^{\circ}, 8.794723^{\circ}$ & 87 & $\begin{array}{c}\text { Deck: Diptera: Nematocera: } \\
\text { Chironomidae or } \\
\text { Ceratopogonidae }\end{array}$ \\
\hline AP6R & & $20: 45$ & $-84.938296^{\circ}, 9.518006^{\circ}$ & 18 & $\begin{array}{l}\text { Deck: Hemiptera: } \\
\text { Scutelleridae } \\
\text { "shield-backed bug" }\end{array}$ \\
\hline (AP6.1R & & $22: 12$ & $-84.861155^{\circ}, 9.660273^{\circ}$ & 12 & Near lights on deck: \\
\hline AP6.2R) & & & $-84.844015^{\circ}, 9.692802^{\circ}$ & & $\begin{array}{l}\text { Lepidoptera: Sphingidae, } \\
\text { Nyceryx ericea (Druce, } \\
1888) \text { (5 individuals) }\end{array}$ \\
\hline PUNTARENAS & $\begin{array}{c}\text { July } 25^{\text {th }}, \\
2017\end{array}$ & $5: 55$ & $-84.835352^{\circ}, 9.980183^{\circ}$ & 0 & $\begin{array}{l}\text { Net \#4: Diptera } \\
\text { Net \#5: Diptera }\end{array}$ \\
\hline
\end{tabular}


TABLE 3

Collections of aerial plankton on transect Puntarenas - Isla del Coco, during August 2018 onboard Okeanos II.

\begin{tabular}{|c|c|c|c|c|c|}
\hline Point & Date & Time & Coordinate & $\begin{array}{c}\text { Distance to nearest } \\
\text { continental land }(\mathrm{km})\end{array}$ & Events \\
\hline PUNTARENAS & \multirow{3}{*}{$\begin{array}{c}\text { August } 12^{\text {th }} \text {, } \\
2018\end{array}$} & $14: 50$ & $-84.835352^{\circ}, 9.980183^{\circ}$ & 0 & - \\
\hline AP1-18 & & $19: 56$ & $-84.993768^{\circ}, 9.382055^{\circ}$ & 23 & $\begin{array}{l}\text { Deck: Hemiptera: Coreidae } \\
\text { "Leaf legged bug" }\end{array}$ \\
\hline AP2-18 & & $20: 45$ & $-85.0414^{\circ}, 9.29134^{\circ}$ & 30 & $\begin{array}{l}\text { Near lights on deck: } \\
\text { Lepidoptera: Sphingidae, } \\
\text { Aellopos ( } 2 \text { individuals) }\end{array}$ \\
\hline AP3-18 & \multirow{3}{*}{$\begin{array}{c}\text { August } 13^{\text {th }}, \\
2018\end{array}$} & $8: 12$ & $-85.74355^{\circ}, 7.988447^{\circ}$ & 187 & - \\
\hline AP4-18 & & $17: 00$ & $-86.265954^{\circ}, 7.011534^{\circ}$ & 309 & - \\
\hline AP5-18 & & $21: 47$ & $-86.561589^{\circ}, 6.456803^{\circ}$ & 378 & - \\
\hline AP6-18 & $\begin{array}{c}\text { August } 14^{\text {th }} \text {, } \\
2018\end{array}$ & $4: 37$ & $-87.012202^{\circ}, 5.610432^{\circ}$ & 484 & - \\
\hline
\end{tabular}

1 or 2 individuals per day (Yoshimoto \& Gressitt, 1960). Moreover, other 5 families (Diptera: Milichiidae; Hemiptera: Scutelleridae and Coreidae; and Lepidoptera: Sphingidae) were collected on the deck of the vessel.

The predaceous midges Ceratopogonidae (Diptera) were the most commonly collected in the aerial nets. They have a worldwide distribution and are associated with aquatic environments. This family has been recorded on Isla del Coco (Hogue \& Miller, 1981; GutiérrezFonseca, Ramírez, Umaña, \& Springer, 2013). The one collected on this study was found $35 \mathrm{~km}$ from the continent, most likely it was carried from the mainland by the wind. Ceratopogonidae have been also found on collection trips on the transect California - Philippines (Yoshimoto \& Gressitt, 1960), Japan (90 km from Kyushu (Yoshimoto \& Gressitt, 1961), Tokyo Bay and Tanegashima (Holzapfel \& Perkins, 1969), the Philippines (3 km from Luzon, $5 \mathrm{~km}$ from Mindoro, $10 \mathrm{~km}$ from Samar; Holzapfel \& Perkins, 1969), $540 \mathrm{~km}$ from Wake Island, Guam, Taiwan and Vietnam (Holzapfel \& Perkins, 1969). They have been even recorded on Antarctic waters (Gressitt et al., 1960; Gressitt et al., 1961).

The other Diptera family identified was Milichiidae, which correspond to a very specialized group with many species with kleptoparasitic behaviors (Albu, 2006). The one from this study was collected on the deck at $92 \mathrm{~km}$ from the mainland. Previously on 1959, the U.S.N.S Barrett recorded the family Milichiidae on different locations across the transect San Francisco-Guam-Japan-Okinawa-KoreaJapan-Honolulu. One specimen was collected at latitude $33^{\circ} \mathrm{N}$ at $200 \mathrm{~km}$ from Amami-Oshima (Japan). Two days after, on the bridge of the same vessel, more than 50 Milichiidae were found alive at $100 \mathrm{~km}$ from South Korea and $500 \mathrm{~km}$ from the China coast (Yoshimoto \& Gressitt, 1960). Other records from the family appear at 50-100 km from South Korea and at $100 \mathrm{~km}$ from Kaua'i (Yoshimoto \& Gressitt, 1961). A piece of thorax identified as potentially Milichiidae was recorded on Antarctic waters in the latitudinal transect between $43^{\circ}-$ $47^{\circ} \mathrm{S}$ in the south of New Zealand $\left(173^{\circ} \mathrm{E}\right)$ (Gressitt et al., 1961).

There are also other two specimens of nonidentified families of Nematoceran flies. One of those individuals corresponds potentially to Scatopsidae, and the other to either Chironomidae or Ceratopogonidae. The family Chironomidae has been previously reported as part of the aerial plankton (Gressitt et al., 1960; Gressitt et al., 1961; Yoshimoto \& Gressitt, 1961), yet not Scatopsidae. The Chironomidae is the second most abundant family on freshwater ecosystems on the island (Gutiérrez-Fonseca et al., 2013). 
The Hymenoptera family Agaonidae (superfamily Chalcidoidea) was less frequent on the reviewed literature. This superfamily is present on Isla del Coco (Hogue \& Miller, 1981) and the one from this study was collected $325 \mathrm{~km}$ from the mainland on the way to the island (167 km from the island). Therefore, most likely it was carried by wind currents. There is only one other record, $5 \mathrm{~km}$ from the coast of Japan $\left(34^{\circ} 30^{\prime} \mathrm{N}, 145^{\circ} 18^{\prime} \mathrm{E}\right)$ (Holzapfel \& Perkins, 1969). These wasps are Ficus (Moraceae) pollinators, and on the island there is one species of these trees (Ficus petusa) (Trusty et al., 2006).

The Coreidae (Hemiptera) reported on this study was found on the deck at $23 \mathrm{~km}$ from the coast. Its proximity to the continent and almost absent presence on other surveys make it very likely that the insect was carried on the boat from land. The only other record of this group corresponds to a head and an abdomen potentially identified as belonging to Coreidae found in Antarctic waters in the latitudinal transect between $43^{\circ}-50^{\circ} \mathrm{S}$ in the south of New Zealand $\left(173^{\circ} \mathrm{E}\right)$ (Gressitt et al., 1960). This family is absent from Isla del Coco (Hogue \& Miller, 1981).

The other family of Hemiptera recorded, Scutelleridae or shield-backed bug, has not been previously reported on this kind of aerial collecting. On this study, it was collected at 18 $\mathrm{km}$ from the mainland on the way back from the island at sunset time. Therefore, probably the insect was attracted to the lights of the boat. This record provides evidence of the minimum distance that a shield-backed bug can be dispersed to the open sea.

The Sphingidae moths were found at 30 $\mathrm{km}$ and $12 \mathrm{~km}$, from the continental coast at nighttime. They correspond to 2 different species one in the genus Aellopos, and Nyceryx ericea (Druce, 1888), respectively. Most likely they were attracted to the lights of the boat powering themselves to that point. Long distance migrations on Lepidoptera have been widely documented and many of them reach continental scales as the Monarch (Danaus plexippus; Urquhart \& Urquhart, 1978) in North America or the Danainae in India (Euploea and Tirumala; Kunte, 2005), so it is not unexpected for a robust month to cover long flight distances. This record presents evidence of the potential home range of these moths, implying that regularly they do offshore incursions of several kilometers. This family of Lepidoptera is present on the island: Agrius cingulata, Erinnyis obscura, Pachylia ficus, and Xylophanes tersa (Hogue \& Miller, 1981; Montoya, 2015), yet not the genera collected.

No spiders were found on this collecting regardless they have been found in other transoceanic trips (Gressitt et al., 1960; Yoshimoto \& Gressitt, 1960; Gressitt et al., 1961; Yoshimoto \& Gressitt, 1961; Holzapfel \& Perkins, 1969) and they are very well known of dispersing through ballooning. Most likely this absence is due to small sampling time.

The present research shows that regardless of the small sample set, the aerial plankton of the Eastern Tropical Pacific includes similar taxa to some of the ones recorded for the rest of the tropical Pacific. Moreover, one family (Ceratopogonidae, Diptera) and one Superfamily (Chalcidoidea, Hymenoptera) of the specimens collected by nets have representatives on Isla del Coco, which could be considered as evidence for a potential colonization mechanism by wind dispersal. Here, we also reported insects which most likely reached the boat by their own means providing evidence of their dispersal abilities. However, due to the small sampling size, this must be considered only as a preliminary result. Adding more replicates on different seasons and additional maritime routes will give a more complete view.

The combination of these field observations with our knowledge on the island community will allow us to answer more general questions about the island colonization process. In particular, does island colonization occurs due to a constant low probability over time, or due to rare events as hurricanes or storms? If the favored mechanism is the first one, we would predict to find representatives of most of the island native species as part of the aerial plankton. While, in the second case, it will 
require to invoke rare events that we might have not witnessed in historical times.

Ethical statement: authors declare that they all agree with this publication and made significant contributions; that there is no conflict of interest of any kind; and that we followed all pertinent ethical and legal procedures and requirements. All financial sources are fully and clearly stated in the acknowledgements section. A signed document has been filed in the journal archives.

\section{ACKNOWLEDGMENTS}

We are grateful to the people who helped us to complete this research. Carlos Víquez during the field collecting, Francisco Urra on the corroboration of family identification for the Sphingidae, José J. Montero for the identification of Nyceryx ericea (Sphingidae) and two anonymous reviewers. In addition to the crew of the SCUBA diving vessels Okeanos I and Okeanos II. We also thank Esteban Herrera, the park rangers and staff from Parque Nacional Isla del Coco; and Melania Muñoz from the Comisión Nacional para la Gestión de la Biodiversidad (R-051-2018-OT-CONAGEBIO) of Costa Rica. This publication was funded by the Percy Sladen Memorial Fund (The Linnean Society of London) and the Herb Levi Memorial Fund for Arachnological Research (American Arachnological Society).

\section{RESUMEN}

Plancton aéreo del Pacífico Tropical Oriental. Introducción: Los invertebrados terrestres pequeños se dispersan de manera pasiva en corrientes de viento, constituyendo lo que se conoce como plancton aéreo, el cual previamente no había sido evaluado en Pacífico Tropical Oriental (PTO). Documentar el plancton aéreo de la Isla del Coco permitiría entender mejor el proceso de colonización de esta diversa isla. Objetivos: Caracterizar el plancton aéreo del transecto Puntarenas - Isla del Coco. Métodos: Los especímenes fueron recolectados utilizando redes entomológicas en 2 viajes de ida y vuelta durante los meses de Julio y Agosto de 2017 y 2018, respectivamente. Resultados: Un total de 10 morfo-especies fueron recolectadas, correspondientes a los órdenes Diptera (Ceratopogonidae,
Milichiidae, y Nematocera de familia no identificada), Hymenoptera (Chalcidoidea: Agaonidae), Hemiptera (Scutelleridae y Coreidae) y Lepidoptera (Sphingidae). Diptera e Hymenoptera fueron recolectados en las redes; mientras que Hemiptera y Lepidoptera fueron encontrados en la cubierta del barco. No se recolectaron arañas. Las familias de Diptera e Hymenoptera, al igual que la familia Coreidae (Hemiptera) han sido previamente registradas en este tipo de muestreos en el PTO. Conclusiones: Dos de los taxones recolectados en las redes, Ceratopogonidae (Diptera) y Chalcidoidea (Hymenoptera), están representados en la Isla del Coco, lo cual provee apoyo directo a la dispersión por viento como un mecanismo de colonización para estos grupos. Igualmente, encontramos otros insectos (Lepidoptera y Hemiptera: Scutelleridae), los cuales probablemente llegaron al barco por sus propios medios, evidenciando sus habilidades de dispersión. Esta investigación entrega datos para responder nuevas preguntas sobre los mecanismos de colonización de islas.

Palabras clave: Dispersión a larga distancia; plancton aéreo; artrópodos; Pacífico Tropical Oriental; Isla del Coco.

\section{REFERENCES}

Albu, V. (2006). Kleptoparasitism, a very unusual relationship between a spider, its bee prey and some clever, opportunistic flies. Entomologica Romanica, $11,87-88$.

Amador, J. A., Durán-Quesada, A. M., Rivera, E. R., Mora, G., Sáenz, F., Calderón, B., \& Mora, N. (2016). The easternmost tropical Pacific. Part II: Seasonal and intraseasonal modes of atmospheric variability. Revista de Biología Tropical, 64, S23-S57.

Bell, J. R., Bohan, D. A., Shaw, E. M., \& Weyman, G. S. (2005). Ballooning dispersal using silk: world fauna, phylogenies, genetics and models. Bulletin of Entomological Research, 95, 69-114.

Bellon, H., Saenz, R., \& Tournon, J. (1983). K-Ar radiometric ages of lavas from Cocos Island (Eastern Pacific). Marine Geology, 54, M17-M23.

Bristowe, W. S. (1931). A preliminary note on the spiders of Krakatau. Proceedings of the Zoological Society, 4, 1387-1401.

Calsbeek, R., \& Smith, T. B. (2003). Ocean currents mediate evolution in island lizards. Nature, 426, 552-555.

Castillo, P., Batiza, R., Vanko, D., Malavassi, E., Barquero, J., \& Fernandez, E. (1988). Anomalously young volcanoes on old hot-spot traces: I. Geology and petrology of Cocos Island. Bulletin of the Geological Society of America, 100, 1400-1414.

Gillespie, R. G., Baldwin, B. G., Waters, J. M., Fraser, C. I., Nikula, R., \& Roderick, G. K. (2012). Long-distance 
dispersal: a framework for hypothesis testing. Trends in Ecology and Evolution, 27, 47-56.

Gressitt, J. L., Leech, R. E., \& O’Brien, C. W. (1960). Trapping of air-borne insects in the Antarctic area. Pacific Insects, 2, 245-250.

Gressitt, J. L., Leech, R. E., Leech, T. S., Sedlacek, J., \& Wise, K. A. J. (1961). Trapping of air-borne insects in the Antarctic area (Part 2). Pacific Insects, 3, 559-562.

Gutiérrez-Fonseca, P. E., Ramírez, A., Umaña, G., \& Springer, M. (2013). Macroinvertebrados dulceacuícolas de la Isla del Coco, Costa Rica: especies y comparación con otras islas del Pacífico Tropical Oriental. Revista de Biología Tropical, 61, 657-668.

Hardy, A. C., \& Cheng, L. (1986). Studies in the distribution of insects by aerial currents. III. Insect drift over the sea. Ecological Entomology, 11, 283-290.

Hogue, C. L., \& Miller, S. E. (1981). Entomofauna of Cocos Island, Costa Rica. Atoll Research Bulletin, 250, 1-29.

Holzapfel, E. P., \& Perkins, Jr B. D. (1969). Trapping of air-borne insects on ships on the Pacific, Part 7. Pacific Insects, 11, 455-476.

Jordano, P. (2017). What is long-distance dispersal? And a taxonomy of dispersal events. Journal of Ecology, $105,75-84$

Kunte, K. (2005). Species composition, sex-ratios and movement patterns in Danaine butterfly migrations in southern India. Journal of the Bombay Natural History Society, 102, 280-286.

Larrivée, M., \& Buddle, C. M. (2011). Ballooning propensity of canopy and understory spiders in a mature temperate hardwood forest. Ecological Entomology, 36(2), 144-151.

Montoya, M. (2015). Chapter 8. Isla del Coco: Terrestrial Ecosystems. In M. Kappelle (Ed.), Costa Rican
Ecosystems (pp. 192- 244). Chicago: The University of Chicago Press.

Morley, E. L., \& Robert, D. (2018). Electric Fields Elicit Ballooning in Spiders. Current Biology, 28, 2324-2330.

Nathan, R., Schurr, F. M., Spiegel, O., Steinitz, O., Trakhtenbrot, A., \& Tsoar, A. (2008). Mechanisms of long-distance seed dispersal. Trends in Ecology and Evolution, 23, 638-647.

Okuma, C., \& Kisimoto, R. (1981). Air Borne Spiders Collected over the East China Sea. Japanese Journal of Applied Entomology and Zoology, 25, 296-298.

Reynolds, A. M., Bohan, D. A., \& Bell, J. R. (2007). Ballooning dispersal in arthropod taxa: conditions at take-off. Biology Letters, 3, 237-240.

Shanks, A. L. (2009). Pelagic larval duration and dispersal distance revisited. Biological Bulletin, 216, 373-385.

Simberloff, D. S., \& Wilson E. O. (1969). Experimental Zoogeography of Islands: The colonization of Empty Islands. Ecology, 50, 278-296.

Urquhart, F. A., \& Urquhart, N. R. (1978). Autumnal migration routes of the eastern population of the monarch butterfly (Danaus p. plexippus L.; Danaidae; Lepidoptera) in North America to the overwintering site in the Neovolcanic Plateau of Mexico. Canadian Journal of Zoology, 56, 1759-1764.

Trusty J. L., Kesler H. C., \& Delgado G. H. (2006). Vascular Flora of Isla del Coco, Costa Rica. Proceedings of the California Academy of Sciences, 57, 247-355.

Yoshimoto, C. M., \& Gressitt, J. L. (1960). Trapping of airborne insects on ships on the Pacific (Part 3). Pacific Insects, 2, 239-243.

Yoshimoto, C. M., \& Gressitt, J. L. (1961). Trapping of airborne insects on ships on the Pacific (Part 4). Pacific Insects, 3, 556-558. 